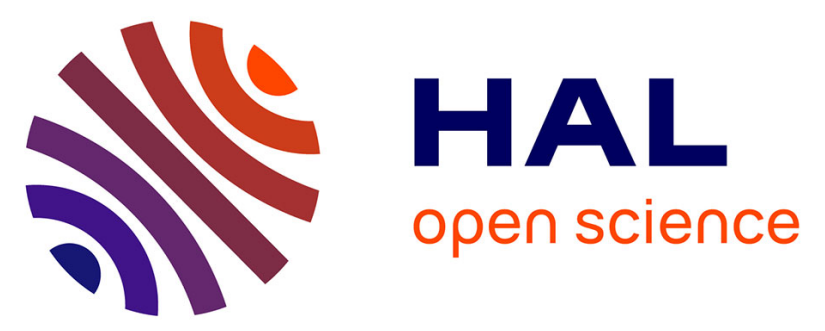

\title{
Long-term temperature evolution in a deep sub-alpine lake, Lake Bourget, France: how a one-dimensional model improves its trend assessment
}

Brigitte Vinçon-Leite, Bruno J. Lemaire, Viet Tran Khac, Bruno Tassin

\section{To cite this version:}

Brigitte Vinçon-Leite, Bruno J. Lemaire, Viet Tran Khac, Bruno Tassin. Long-term temperature evolution in a deep sub-alpine lake, Lake Bourget, France: how a one-dimensional model improves its trend assessment. Hydrobiologia, 2014, European Large Lakes III. Large lakes under changing environmental conditions, 731 (1), pp.49-64. 10.1007/s10750-014-1818-4 . hal-00967616

\section{HAL Id: hal-00967616 \\ https: / hal-enpc.archives-ouvertes.fr/hal-00967616}

Submitted on 26 Jun 2018

HAL is a multi-disciplinary open access archive for the deposit and dissemination of scientific research documents, whether they are published or not. The documents may come from teaching and research institutions in France or abroad, or from public or private research centers.
L'archive ouverte pluridisciplinaire HAL, est destinée au dépôt et à la diffusion de documents scientifiques de niveau recherche, publiés ou non, émanant des établissements d'enseignement et de recherche français ou étrangers, des laboratoires publics ou privés. 


\section{Long-term temperature evolution in a deep sub-alpine lake, Lake Bourget, France: how a one-dimensional model improves its trend assessment}

Brigitte Vinçon-Leite ${ }^{1, *}$

Phone +33-164153642

Fax $+33-164153764$

Email bvl@leesu.enpc.fr

Bruno J. Lemaire 1,2

Viet Tran Khac 1

Bruno Tassin 1

1 LEESU (UMR MA-102) Université Paris-Est, Ecole des Ponts

ParisTech, AgroParisTech, 77455 Marne-la-Vallée, France

2 AgroParisTech, 75005 Paris, France

\section{Abstract}

Water temperature and the alternation of stratification and mixing count amongst key drivers of lake ecology. Reliable long time-series of water temperature are rare. Here, we investigated how a numerical model can fill the gaps in heterogeneous time-series and make it possible to identify a significant trend in the lake thermal regime. We computed the mean water temperature and the Schmidt stability, an indicator of the stratification strength, in a deep and well-stratified lake (Lake Bourget, France), between 1976 and 2008. We first used temperature measurements and then a one-dimensional vertical model, which we describe here. The model performs as well as the best existing models. During the 1976-2008 periods, whereas no statistically significant trend came out of the measurements, we found in the simulation results an increase of $0.12{ }^{\circ} \mathrm{C}$ per decade in the water temperature and of 5.9 days per decade in the stratification duration. This shows that the temperature history of a lake can 
be reconstructed and a reliable long-term trend computed when weather data and a calibrated temperature model are available. Our results also suggest that different local climatic influences cause a slower warming in this lake of the south-western Alps than in other sub-alpine lakes.

\section{Keywords}

Lake temperature

One-dimensional vertical model

Climate variability

South-western Alps

Guest editors: D. Straile, D. Gerdeaux, D. M. Livingstone, P. Nõges, F. Peeters \& K.-O. Rothhaupt / European Large Lakes III. Large lakes under changing environmental conditions

\section{Introduction}

Lakes are considered as good sentinels of global changes because they respond to the changes in their catchment and in the atmosphere (Adrian et al., 2009; Schindler, 2009). It is currently acknowledged that global and regional climate changes have a significant impact on the thermal regimes of surface freshwaters, and particularly of lakes (Livingstone, 2003; Dokulil et al., 2010). In many lakes, surface temperatures have increased in the last few decades (Livingstone \& Dokulil, 2001; Adrian et al., 2009; Reynolds et al., 2012). By contrast, hypolimnetic temperatures display variable trends, depending on the lake bathymetry and location (Stefan et al., 1998; Fang \& Stefan, 1999; Dokulil et al., 2006; Rosner et al., 2012).

Sub-alpine lakes present many similar patterns (e.g. morphometric characteristics, including great depth) (Dokulil \& Teubner, 2005). Their catchments are generally densely populated and host highly urbanized areas. Since the mid-20th century, most sub-alpine lakes have a similar history of eutrophication. Many of them present a recovery trend following the restoration policy implemented since the 1980s (Salmaso et al., 1997; Anneville \& Pelletier, 2000; Dokulil \& Teubner, 2005; Jacquet et al., 2005; Thies et al., 2012).

Sub-alpine lakes are highly influenced by climate warming. Results obtained from several Swiss lakes of large and medium depth, during the mild winter of 2006-2007, indicate that a higher winter thermal stability due to climate 
warming may inhibit the complete mixing of deep, monomictic lakes (Rempfer et al., 2010). These changes in the mixing regime of deep lakes trigger significant changes in their biogeochemical and ecological cycles: incomplete mixing during mild winter will limit the supply of nutrients from the deepest part of the hypolimnion and therefore the phytoplankton biomass in spring and summer (Straile et al., 2010; Salmaso \& Cerasino, 2012).

In consequence, water temperature constitutes a good indicator of a lake's physical response to climate change. It is also very useful for understanding the cascading effects of meteorological forcing on the ecological behaviour of the lake. Frequently, in studies analysing the influence of climate factors on the ecological system, air temperature is used as a proxy for water temperature in the epilimnion (Anneville et al., 2002; Gallina et al., 2013). But correlations between the meteorological variables and the lake ecological variables are not sufficient for explaining the complex response of the ecosystem to the meteorological forcing. It is necessary to assess, through measurements or modelling, the distribution of the water temperature in the water column. Even if water temperature is easily measurable, long-term series of temperature profiles are only available for a few well-monitored lakes, e.g. Lake Geneva, Lake Constance, Lake Zürich, Mondsee and Lake Garda. These long-term data sets (Livingstone \& Dokulil, 2001; Livingstone, 2003; Dokulil et al., 2006) have been used to study the response of lake temperature to climate forcing. For many lakes, including our study site, Lake Bourget, reliable data sets are only available for discontinuous periods, and/or the sampling frequency is not sufficient for detecting significant trends (Rosner et al., 2012). Furthermore, when temperature data exist, they have frequently been obtained using heterogeneous devices during the study period. Another limitation to the assessment of the long-term trend comes from the unavailability of non-public data. When the monitoring frequency is low, the linear interpolation of the water temperature between the sampling dates provides inaccurate values since its time evolution as a function of meteorological forcing is non-linear, especially during the stratification period.

Unlike water temperature data, reliable, long-term meteorological time-series are often available in the neighbourhood of many lakes. In this case, a deterministic temperature model, using meteorological data as forcing variables, may constitute a valuable tool for reconstituting the water temperature profiles at a relevant time-step, i.e. daily in our case. Moreover, it 
makes possible the computation of the duration of the mixing and stratification periods.

In deep sub-alpine lakes, modelling the water column temperature can be performed in a reliable way using a one-dimensional vertical temperature model. Since the 1960s, many such temperature models have been developed (Imberger \& Patterson, 1981; Hondzo \& Stefan, 1993; Hostetler \& Small, 1999 ; Goudsmit et al., 2002; Mironov, 2008) and used for various purposes including the assessment of the response of lakes to climate change scenarios (Stefan et al., 1998; Fang \& Stefan, 1999; Hostetler, 2009). During the last decade, long-term simulations have been performed with these temperature models on sub-alpine lakes, e.g. Lake Zürich (Peeters et al., 2002 ), Lake Geneva (Perroud et al., 2009) and Lake Ammer (Weinberger \& Vetter, 2012). Some of these studies only cover a medium-term period, for example 10 years for Lake Geneva (Perroud et al., 2009) and 7 years (2002-2008) for Lake Ammer (Bueche \& Vetter, 2013). Valuable insights have been gained into the influence of climate change on the thermal regimes of sub-alpine lakes, but only very few attempts have been made to model the deep lakes of the southwestern fringe of the Alps, which may exhibit a different behaviour since the influence of the Mediterranean Sea and of the Atlantic Ocean is stronger than in the Central Alps (Brunetti et al., 2009; Salmaso, 2012).

To our knowledge, few studies have used both measurements and model results to assess trends in water temperature and thermal structure of deep lakes. In this paper, we investigate through data analysis and modelling, the thermal behaviour of Lake Bourget during the three last decades, using this study site as a representative of the sub-alpine lakes located in the southern French Alps. We recall the main features of the one-dimensional vertical thermal model we used in this study. The model parameters are calibrated using the reliable measurements from 1976 to 1988, and the performance of the model is validated using the most reliable data from the year 2000. The results obtained during a 33-year continuous simulation, from 1976 to 2008 , are presented. Finally, we illustrate how the model can provide surrogates for missing measurements and help in assessing reliably the long-term evolution of water temperatures and thermal stability in the lake.

\section{Methods}

\section{The temperature model}

The unidimensional vertical temperature model applied in this study uses an 
eddy diffusivity formulation based on the Richardson number. More sophisticated models are based on two-equation turbulence closures, especially the $k-\varepsilon$ parameterization as in SIMSTRAT (Goudsmit et al., 2002).

The temperature model originates in the work of Simons (1981) on Lake Ontario. The large size of this lake $\left(19,000 \mathrm{~km}^{2}\right)$ justified the use of oceanic equations for eddy diffusivity. Henderson-Sellers (1985) adapted these equations and applied them to Lake Windermere (UK, $14.7 \mathrm{~km}^{2}$ ). Hostetler later used them in his model (Hostetler \& Small, 1999). For relatively small lakes, these equations seem to work adequately even if they are only strictly valid for the ocean and very large lakes.

In the mid-eighties, Chahuneau used the same modelling approach in the development of a one-dimensional model of a relatively small lake, Lake Nantua, France (1.4 km²) (Chahuneau et al., 1983; Chahuneau, 1984). Tassin (1986) adapted this approach using different equations for the eddy diffusivities in the epilimnion and hypolimnion and implemented it on Lake Geneva $\left(580 \mathrm{~km}^{2}\right)$. It was then implemented on Lake Bourget, France $\left(42 \mathrm{~km}^{2}\right)$ (Vinçon-Leite et al., 1989; Vinçon-Leite, 1991). The model is fully described in French in Vinçon-Leite et al. (1989). We thought it useful to recall and briefly discuss its main features. The model is based on the horizontally averaged diffusion equation for temperature (Eq. 1).

$$
\frac{\partial T(z, t)}{\partial t}=\frac{1}{A(z)} \frac{\partial}{\partial z}\left[A(z) K(z, t) \frac{\partial T(z, t)}{\partial z}+\frac{A(z) S S(z, t)}{\rho_{0} c_{p}}\right]
$$

where $T(z, t)$ is the water temperature $\left({ }^{\circ} \mathrm{C}\right)$ at time $t$ and depth $z, A(z)$ is the horizontal area $\left(\mathrm{m}^{2}\right)$ of the lake at depth $z, K(z, t)$ is the vertical diffusion coefficient $\left(\mathrm{m}^{2} \mathrm{~s}^{-1}\right), S S(z, t)$ is the heat sources and sinks $\left(\mathrm{W} \mathrm{m}^{-2}\right), \rho_{0}$ is the average water mass density $\left(1,000 \mathrm{~kg} \mathrm{~m}^{-3}\right)$ and $c_{p}$ is the specific heat of water at constant pressure $\left(4,180 \mathrm{~J} \mathrm{~kg}^{-1} \mathrm{~K}^{-1}\right)$. The molecular diffusion component of the diffusion coefficient is negligible compared to the eddy diffusivity.

Formulation of eddy diffusivity

In the model, different formulations are used for the eddy diffusivity above and below the thermocline, depth $z_{\text {th }}$ of which is defined by the location of the maximum density gradient.

From the surface to the thermocline

The eddy diffusivity from the surface to the thermocline is formulated after 
Simons (1981). It is first calculated for neutral conditions (homogeneous mass density along the vertical). Turbulence is classically described with Boussinesq's turbulent viscosity $v_{\mathrm{t}}(z)\left(\mathrm{m}^{2} \mathrm{~s}^{-1}\right)$, Prandtl's mixing length $l_{\mathrm{m}}(\mathrm{m})$ and the friction velocity $u^{*}(z)\left(\mathrm{m} \mathrm{s}^{-1}\right)$ :

$$
\begin{gathered}
\tau(z)=\rho(z)\left(u^{*}(z)\right)^{2}=\rho(z) l_{m}^{2}\left(\frac{\partial u}{\partial z}(z)\right)^{2} \\
\nu_{\mathrm{t}}(z)=-l_{m}^{2} \frac{\partial u}{\partial z}(z)
\end{gathered}
$$

where $\tau(z)$ is the Reynolds' turbulent shear and $u(z)$ is the average horizontal current velocity $\left(\mathrm{m} \mathrm{s}^{-1}\right)$. The average horizontal current velocity $u(z)$ is assumed to decrease exponentially with a characteristic length $D(\mathrm{~m})$ proportional to the surface friction velocity $u_{s}^{*}\left(\mathrm{~m} \mathrm{~s}^{-1}\right)$ :

$$
\begin{gathered}
u(z)=u(0) \exp (-z / D) \\
D=\gamma u_{s}^{*}
\end{gathered}
$$

where $\gamma$ is a calibration parameter $(s)$. The mixing length is taken to be a fixed fraction of the characteristic length $D$, as in the ocean surface layer model of Mellor and Durbin (1975):

$$
l_{m}=\delta D
$$

where $\delta$ is a calibration parameter (-). The eddy diffusivity in neutral conditions $K_{0}(z)$ is assimilated into the turbulent viscosity $v_{\mathrm{t}}(z)$. Combining the previous equations yield the formulation of the eddy diffusivity in neutral conditions (Table 1). After Simons (1981), the impacts of the wind and of stratification are decoupled: the eddy diffusivity $K(z)\left(\mathrm{m}^{2} \mathrm{~s}^{-1}\right)$ of a stratified lake is taken as the product of the eddy diffusivity in neutral conditions $K_{0}(z)$ and of an empirical function of the Richardson number $\mathcal{R}_{i}(z)(-)$, which characterizes the lake stratification (Table 1 ). This function sharply reduces eddy diffusivity close to the thermocline.

\section{Table 1}

Equations describing the eddy diffusivity from the surface to the thermocline $\left(z \leq z_{\mathrm{th}}\right)$

$$
K_{0}(z)=\gamma \delta u_{s}^{* 2} \exp \left(-\frac{z}{\gamma u_{s}^{*}}\right)
$$




\begin{tabular}{|c|c|}
\hline$K(z)$ & $\frac{K_{0}(z)}{+\sigma \mathcal{R}_{i}(z)}$ \\
\hline$u_{s}^{*}=$ & $\overline{\gamma^{\prime}} \frac{\rho_{a}}{\rho_{0}} U$ \\
\hline $\mathcal{R}_{i}(z)$ & $N(z)^{2}\left(\frac{\partial u}{\partial z}\right)^{-2}=(N(z) \gamma \delta)^{2} \exp \left(\frac{2 z}{D}\right)$ \\
\hline$N(z)$ & $\sqrt{\frac{g}{\rho(z)}\left|\frac{\partial \rho}{\partial z}\right|}$ \\
\hline$K(z)$ & Eddy diffusivity in non-neutral conditions $\left(\mathrm{m}^{2} \mathrm{~s}^{-1}\right)$ \\
\hline$K_{0}(z)$ & Eddy diffusivity in neutral conditions $\left(\mathrm{m}^{2} \mathrm{~s}^{-1}\right)$ \\
\hline$u_{\mathrm{s}}^{*}$ & Surface friction velocity $\left(\mathrm{m} \mathrm{s}^{-1}\right)$ \\
\hline$C_{\mathrm{d}}$ & Wind drag coefficient $\left(1.8 \times 10^{-3}\right)$ \\
\hline$\rho_{0}$ & Average water density $\left(1,000 \mathrm{~kg} \mathrm{~m}^{-3}\right)$ \\
\hline$\rho_{a}$ & Average air mass density $\left(1.293 \mathrm{~kg} \mathrm{~m}^{-3}\right)$ \\
\hline$U$ & Wind speed at $10 \mathrm{~m}$ above the lake surface $\left(\mathrm{m} \mathrm{s}^{-1}\right)$ \\
\hline $\mathcal{R}_{i}(z)$ & Richardson number (-) \\
\hline$N(z)$ & Brunt-Väisälä frequency $(\mathrm{Hz})$ \\
\hline$u(z)$ & Average horizontal current velocity $\left(\mathrm{m} \mathrm{s}^{-1}\right)$ \\
\hline$z$ & Depth (m) \\
\hline$g$ & Acceleration of gravity $\left(\mathrm{m} \mathrm{s}^{-2}\right)$ \\
\hline$\rho(z)$ & Water mass density $\left(\mathrm{kg} \mathrm{m}^{-3}\right)$ \\
\hline$\gamma$ & Calibration parameter (s) \\
\hline$\delta, \sigma$ & Calibration parameters (-) \\
\hline
\end{tabular}

Below the thermocline

Below the thermocline, the wind acts only indirectly on the mixing, especially through internal waves (MacIntyre et al., 1999; Lorke, 2007; Cuypers et al., 2011 ; Le Vu et al., 2011). A different formulation for the eddy diffusivity is required (Table 2). It is taken as a power function of the Brunt-Väisälä frequency $N(z)$, which is supported by empirical evidence (Imberger \& Patterson, 1990). Since the complex processes of energy dissipation are not physically described in the model, a fitting parameter $\alpha$ is introduced in order 
to reduce the eddy diffusivity at the thermocline. In the model, the boundary between the metalimnion and the hypolimnion is the depth $z_{\mathrm{m}}$ at which the density gradient equals the threshold value of $10^{-5} \mathrm{~kg} \mathrm{~m}^{-4}$. The geothermal flux at the lake bottom is neglected. A reduction factor, linearly dependent on depth, is applied in the hypolimnion to reach a zero-flux condition at the lake bottom (Tassin, 1986).

\section{Table 2}

Equations describing the eddy diffusivity below the thermocline $\left(z_{\mathrm{th}}<z \leq z_{\max }\right)$

\begin{tabular}{|l|l|}
\hline $\begin{array}{l}\text { for } z_{\mathrm{th}}<z \leq z_{m} \\
\text { for } \\
z_{m}<z \leq z_{\mathrm{max}}\end{array}$ & $\begin{array}{l}K(z)=\alpha K\left(z_{\mathrm{th}}\right)\left[\frac{N\left(z_{\mathrm{th}}\right)}{N(z)}\right]^{2 p_{2}} \text { in the lower part of the } \\
\text { metalimnion }\end{array}$ \\
\hline$z_{\mathrm{th}}$ & $\begin{array}{l}\text { Depth of the thermocline (m) } \\
\text { Depth of the boundary between the metalimnion and the } \\
\text { hypolimnion (m) }\end{array}$ \\
\hline$z_{\mathrm{m}}$ & $\left.\begin{array}{l}\left.\text { Eddy diffusivity (m }{ }^{2} \mathrm{~s}^{-1}\right) \\
K(z)\end{array}\right]^{2 p_{2}}$ in the hypolimnion \\
\hline$K(z)$ & Brunt-Väisälä frequency (Hz) \\
\hline$N(z)$ & Calibration parameters (-) \\
\hline$\alpha, p_{2}$ & Maximum lake depth (m) \\
\hline$z_{\max }$ &
\end{tabular}

Formulation of the heat fluxes

The net heat flux $S S(0, t)$ at the lake-atmosphere interface and $S S(z, t)$ at depth $z$ in the water column are computed according to classical empirical formulations (Henderson-Sellers, 1984), as described in Table 3.

\section{Table 3}

Equations describing the continuity of the heat flux at the lake surface and in the wat $\epsilon$

$$
\begin{aligned}
& -\rho_{0} c_{p} K(0, t) \frac{\partial T}{\partial z}(0, t)=S S(0, t)=\left(1-A_{s}\right) Q_{\mathrm{sol}}^{0}(t)+Q_{a}(t)-Q_{w}(t)-Q_{l}(i) \\
& Q_{\mathrm{sol}}^{0}=\zeta Q_{\mathrm{extra}}\left(1-0.65 C_{a}^{2}\right) \\
& Q_{a}=\varepsilon_{a} \sigma_{\mathrm{SB}}\left(T_{a}+273.15\right)^{4} \text { where } \varepsilon_{a}=0.93710^{-5}\left(1+0.17 C_{a}^{2}\right)\left(T_{a}+273.15\right)^{2} \\
& Q_{w}=\varepsilon_{w} \sigma_{\mathrm{SB}}(T(0, t)+273.15)^{4}
\end{aligned}
$$




$$
\begin{aligned}
& Q_{l}=(A T(0, t)+B) \rho_{0} U\left(e_{\text {sat }}-e_{a}\right) \mathcal{L}(T(0, t)) \\
& e_{\text {sat }}=\exp \left[2.3026\left(\frac{7.5 T(0, t)}{T(0, t)+237.3}+0.7858\right)\right] \\
& \mathcal{L}(T(0, t))=2.50110^{6}-2.36510^{3} T(0, t) \\
& Q_{s}=C \rho_{0} U P_{a}\left(T(0, t)-T_{a}\right) \mathcal{L}(T(0, t)) \\
& S S(z, t)=Q_{\text {sol }}(z, t)=\left(1-A_{s}\right)(1-\beta) Q_{\text {sol }}^{0}(t) \exp (-\eta z) \text { for } 0<z \leq z_{\max } \\
& \beta=0.265 \ln \eta+0.614 \quad(\text { Williams et al., } 1981)
\end{aligned}
$$

$\rho_{0} \quad$ Average water mass density $\left(1,000 \mathrm{~kg} \mathrm{~m}^{-3}\right)$

$c_{p} \quad$ Specific heat of water at constant pressure $\left(4180 \mathrm{~J} \mathrm{~kg}^{-1} \mathrm{~K}^{-1}\right)$

z $\quad$ Depth (m)

$K(z, t) \quad$ Vertical diffusion coefficient $\left(\mathrm{m}^{2} \mathrm{~s}^{-1}\right)$

$T(z, t) \quad$ Water temperature $\left({ }^{\circ} \mathrm{C}\right)$

$S S(z, t) \quad$ Heat sources and sinks $\left(\mathrm{W} \mathrm{m}^{-2}\right)$

$A_{\mathrm{s}} \quad$ Albedo at the lake surface (0.03)

$Q_{\text {sol }}{ }^{0} \quad$ Intensity of the incident short wave solar radiation $\left(\mathrm{W} \mathrm{m}^{-2}\right)$

$Q_{a} \quad$ Infrared radiation from sky $\left(\mathrm{W} \mathrm{m}^{-2}\right)$

$Q_{w} \quad$ Infrared radiation from lake surface $\left(\mathrm{W} \mathrm{m}^{-2}\right)$

$Q_{l} \quad$ Latent heat flux $\left(\mathrm{W} \mathrm{m}^{-2}\right)$

$Q_{s} \quad$ Sensible heat flux $\left(\mathrm{W} \mathrm{m}^{-2}\right)$

$\zeta \quad$ Screening factor due to the mountains (dimensionless calibration paramet

$Q_{\text {extra }}$ Intensity of the solar radiation at the top of the atmosphere $\left(\mathrm{W} \mathrm{m}^{-2}\right)$

$C_{a} \quad$ Cloud cover (-)

$\varepsilon_{a} \quad$ Emissivity of the atmosphere (-)

$\sigma_{\mathrm{SB}} \quad$ Stefan-Boltzmann constant $\left(5.67 \times 10^{-8} \mathrm{~W} \mathrm{~m}^{-2} \mathrm{~K}^{-4}\right)$

$T_{a} \quad$ Air temperature $\left({ }^{\circ} \mathrm{C}\right)$

\begin{tabular}{l|l}
$\varepsilon_{w}$ & Emissivity of water (0.97)
\end{tabular}

$A, C \quad$ Calibration parameters $\left(\mathrm{Pa}^{-1}{ }^{\circ} \mathrm{C}^{-1}\right)$

$B \quad$ Calibration parameter $\left(\mathrm{Pa}^{-1}\right)$

$U \quad$ Wind speed at $10 \mathrm{~m}$ above water level $\left(\mathrm{m} \mathrm{s}^{-1}\right)$ 


\begin{tabular}{l|l}
$e_{\text {sat }}$ & Water vapour saturation pressure $(\mathrm{hPa})$ \\
\hline$e_{a}$ & Atmospheric water vapour pressure $(\mathrm{hPa})$ \\
\hline $\mathcal{L}(T)$ & Latent heat of evaporation at water temperature $T\left(\mathrm{~J} \mathrm{~kg}^{-1}\right)$ \\
\hline$P_{a}$ & Air pressure $(\mathrm{hPa})$ \\
\hline$\beta$ & Fraction of the short wave solar radiation absorbed at the lake surface $(-)$ \\
\hline$\eta$ & Light extinction coefficient $\left(\mathrm{m}^{-1}\right)$ \\
\hline$z_{\max }$ & Lake maximum depth $(\mathrm{m})$ \\
\hline
\end{tabular}

To represent the convective mixing due to the cooling of the surface layers, unstable density profiles are homogenized.

Indicators of the model performance

The performance of a model has to be assessed by comparing the results with those of other models applied to similar lakes. Many applications of one-dimensional temperature models can be found in the literature, but the metrics used for assessing the quality of the models are rarely available. Frequently, the agreement between measurements and model results is assessed qualitatively by visual estimation (Goudsmit et al., 2002). We have selected commonly used indicators (Peeters et al., 2002; Perroud et al., $2009)$ : the mean temperature error $\left(T_{\mathrm{me}}\right)$, the standard deviation of the error $\left(T_{\text {sde }}\right)$ and the root mean square of the errors $\left(T_{\text {rmse }}\right)$, computed according to equations described in Table 4. The measured temperature profiles are linearly interpolated every metre, to facilitate comparison with the simulation results.

\section{Table 4}

Equations describing the performance indicators of the thermal model

\begin{tabular}{|l|l|}
\hline$T_{\mathrm{me}}$ & $=\frac{1}{n m} \sum_{i=1}^{n} \sum_{j=1}^{m}\left[e\left(t_{i}, z_{j}\right)\right]$ \\
\hline$e\left(t_{i}, z_{j}\right)$ & $=T_{\text {mod }}\left(t_{i}, z_{j}\right)-T_{\text {data }}\left(t_{i}, z_{j}\right)$ \\
\hline$T_{\text {sde }}$ & $=\left(\frac{1}{n(m-1)} \sum_{i=1}^{n} \sum_{j=1}^{m}\left[e\left(t_{i}, z_{j}\right)-T_{\mathrm{me}}\right]^{2}\right)^{\frac{1}{2}}$ \\
\hline$T_{\text {rmse }}$ & $=\left(\frac{1}{n m} \sum_{i=1}^{n} \sum_{j=1}^{m}\left[e\left(t_{i}, z_{j}\right)\right]^{2}\right)^{\frac{1}{2}}$
\end{tabular}




\begin{tabular}{|l|l}
\hline$T_{\text {data }}\left(t_{i}, z_{j}\right), T_{\text {mod }}\left(t_{i}, z_{j}\right)$ & $\begin{array}{l}\text { Measured and simulated temperatures at depth } z_{j} \text { on the } \\
i \text { th profile at time } t_{i}\end{array}$ \\
\hline$n$ & Number of sampling days \\
\hline$m$ & Number of layers in the model
\end{tabular}

Water column stability

The stability index $W_{\mathrm{S}}$ of the water column, elaborated by Schmidt (1928), is an indicator of the stratification strength. It represents the work per unit surface area necessary to bring the lake from a density stratification $\rho(z)$ to a uniform volume-averaged density $\langle\rho\rangle$. We examine the evolution of annual and seasonal means of the Schmidt stability. We also use it to determine the dates of the beginning and end of the seasonal stratification, when the stability exceeds a site-dependent threshold.

The volume average $\langle X\rangle$ of any variable $X(z)$ is computed according to Eq. 7 .

$$
\langle X\rangle=\frac{1}{V} \int_{0}^{z_{\max }} X(z) A(z) \mathrm{d} z,
$$

where $V$ is the lake volume, $z_{\max }$ is the lake maximum depth and $A(z)$ is the lake area at depth $z$.

The stability index is computed according to Eq. 8 (Hutchinson, 1957).

$$
W_{S}=\frac{g V}{A_{0}}(\langle\rho z\rangle-\langle\rho\rangle\langle z\rangle)=\frac{g V\langle\rho\rangle}{A_{0}}\left(z_{g}-z_{v}\right)
$$

where $g$ is the acceleration of gravity, $A_{0}$ is the lake surface area, and $z_{v}$ (or $\langle z\rangle)$ and $z_{g}$ are the depths of the centres of volume and of mass, respectively. To compute the stability index using the field data, the measured density profiles of sufficient depth resolution are linearly interpolated every metre. Then the daily means of the density $\langle\rho\rangle$, the depth of the centre of gravity $z_{g}$ and the stability index $W_{S}$ are computed.

AQ1

\section{The study site}

Lake Bourget is a deep (maximum depth $145 \mathrm{~m}$ and mean depth $80 \mathrm{~m}$ ), long $(18 \mathrm{~km})$, narrow $(2.5 \mathrm{~km})$ and well-stratified lake, located in the French Alps 
$\left(45^{\circ} 44^{\prime} \mathrm{N}, 5^{\circ} 52^{\prime} \mathrm{E}\right)$ at $231-\mathrm{m}$ altitude (Fig. 1). Inflow and outflow are small in comparison with the lake volume, and the water residence time is around 10 years, so the use of a one-dimensional model is justified. The water level does not vary naturally as it is regulated by the Savières sluice. For management purposes (harbour dredging, reedbed conservation), limited level variations occur for a few weeks (Miquet, 1997).

\section{Fig. 1}

Location of Lake Bourget in France and bathymetric map of Lake Bourget. The monitoring is conducted at point $B$, the deepest point of the lake

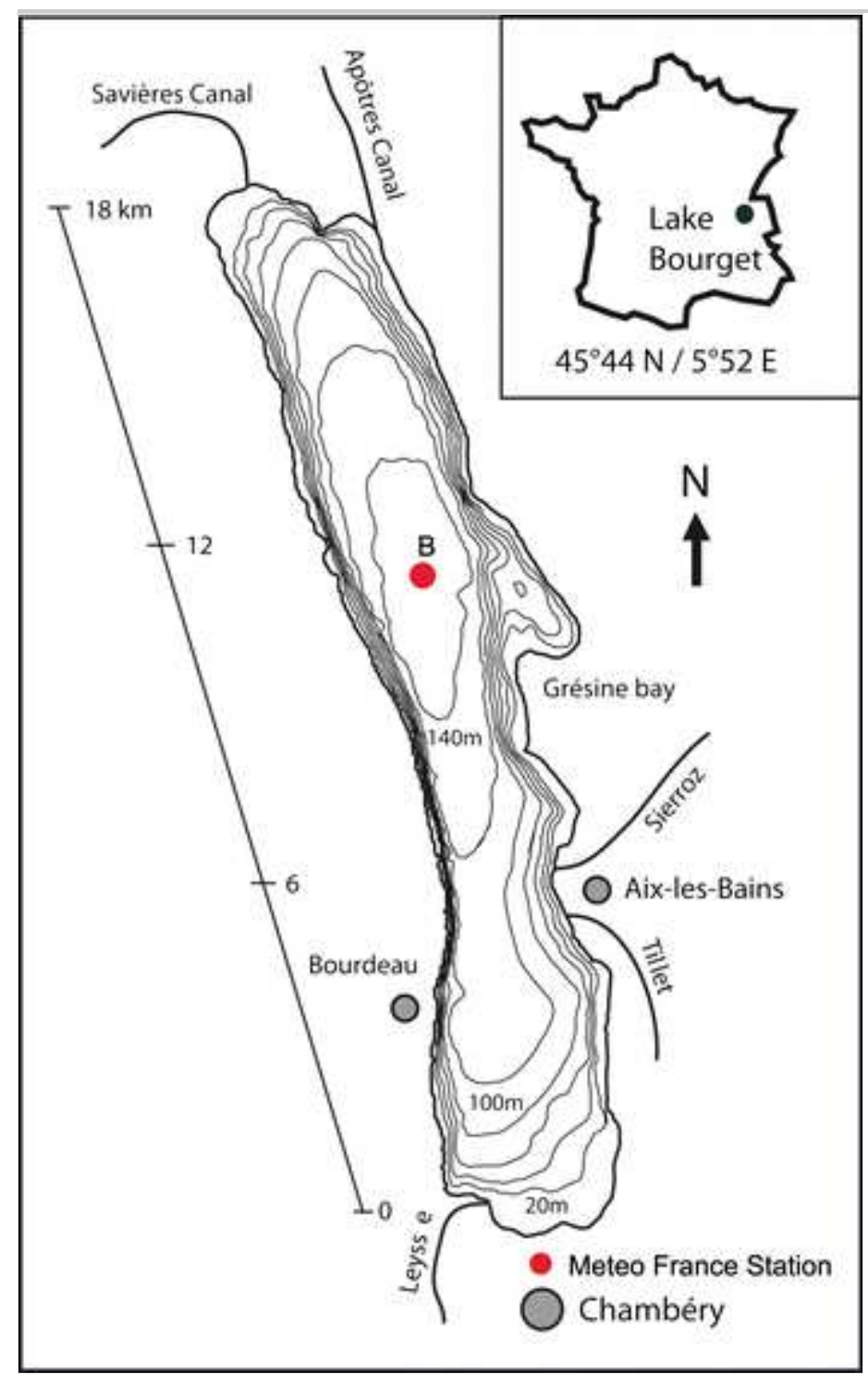

Lake Bourget is a warm, facultatively monomictic lake, where complete overturn does not occur during mild winters. The accumulation of heat in the hypolimnion during consecutive mild winters results in an increase of the deep-water temperature. This constitutes a key feature to be represented by the 
thermal model.

The meteorological data of the study period (1976-2008) were measured at the southern end of the lake (Voglans station) by the French Meteorological Institute (Météo-France).

During the study period, the lake temperature measurements were conducted at the deepest point of the lake, point B, by several institutions: Centre d'Etude du Machinisme Agricole, du Génie Rural, des Eaux et des Forêts (CEMAGREF), Institut National de la Recherche Agronomique (INRA), Comité InterSyndical pour l'Assainissement du Lac du Bourget (CISALB) and during several research projects with different devices. Their frequency and accuracy have improved with time. Between 1976 and 1982, the temperature measurements were conducted by CEMAGREF, from 1976 to 1980 with a thermometer in water sampled at fixed depths (accuracy $0.1{ }^{\circ} \mathrm{C}$ ) and in 1981-1982 with a thermistor. Since 1984, the Cellule technique du lac du Bourget (thereafter CT LdB) has been involved in the regular lake monitoring. Between 1984 and 1987, water temperature was measured with a temperature sensor (Ponselle France). Since 1988, many research projects conducted by Leesu-Ecole des Ponts have been carried out jointly with CT LdB. From 1988 on, CTD probes were used: between 1988 and 1996 a probe from Meerestechnik Elektronik (Germany, accuracy $0.005^{\circ} \mathrm{C}$ ) and from 1996 to 2008, a Seabird probe (SBE 19, USA, accuracy $0.001{ }^{\circ} \mathrm{C}$ ). The number of sampling dates per year is highly variable during the study period: from 0 (no public data availability) to 36 sampling dates evenly distributed throughout the year (2000).

\section{Calibration of the model parameters}

The model was run with 1-m-deep layers and a 3-h time step. The daily results correspond to 24-h averaged outputs. The Secchi depths used for computing the light extinction coefficient were interpolated linearly between the sampling dates. The lake temperature data set was scrutinised for inconsistent and inaccurate data, which were then discarded. The values of the model parameters (Table 5 ) were obtained by an empirical calibration process based on minimizing the differences between the model results and the selected measured values $\left(T_{\text {me }}\right)$, during the 1976-1988 periods. The best parameter set was defined by a qualitative, iterative trial-and-error process, comparing the modelled and measured temperature profiles and the timing of stratification and mixing. 
Table 5

Calibrated parameter values (1976-1988)

\begin{tabular}{|l|l|}
\hline$A$ & $1.14 \times 10^{-9} \mathrm{~Pa}^{-1}{ }^{\circ} \mathrm{C}^{-1}$ \\
\hline$B$ & $2.75 \times 10^{-7} \mathrm{~Pa}^{-1}$ \\
\hline$C$ & $2.35 \times 10^{-12} \mathrm{~Pa}^{-1}{ }^{\circ} \mathrm{C}^{-1}$ \\
\hline$\sigma$ & 9.46 \\
\hline$\gamma$ & $570 \mathrm{~s}$ \\
\hline$\delta$ & 0.015 \\
\hline$\alpha$ & 0.173 \\
\hline$p_{2}$ & 0.605 \\
\hline
\end{tabular}

\section{Results}

Verification of the model performance

Validation of the model was performed by comparing the results to the measured data in the year 2000. This year was selected because of the quality and quantity of measurements: 36 sampling dates evenly distributed from 5 January to 18 December 2000. Six pairs of simulated and measured profiles, representative of the seasonal evolution of the temperature, are presented in Fig. 2. The value of the annual root mean square error $\left(T_{\text {rmse }}\right)$ is $0.37{ }^{\circ} \mathrm{C}$.

\section{Fig. 2}

Vertical temperature profiles in Lake Bourget in 2000 based on measurements (dots) and model simulations (lines) 

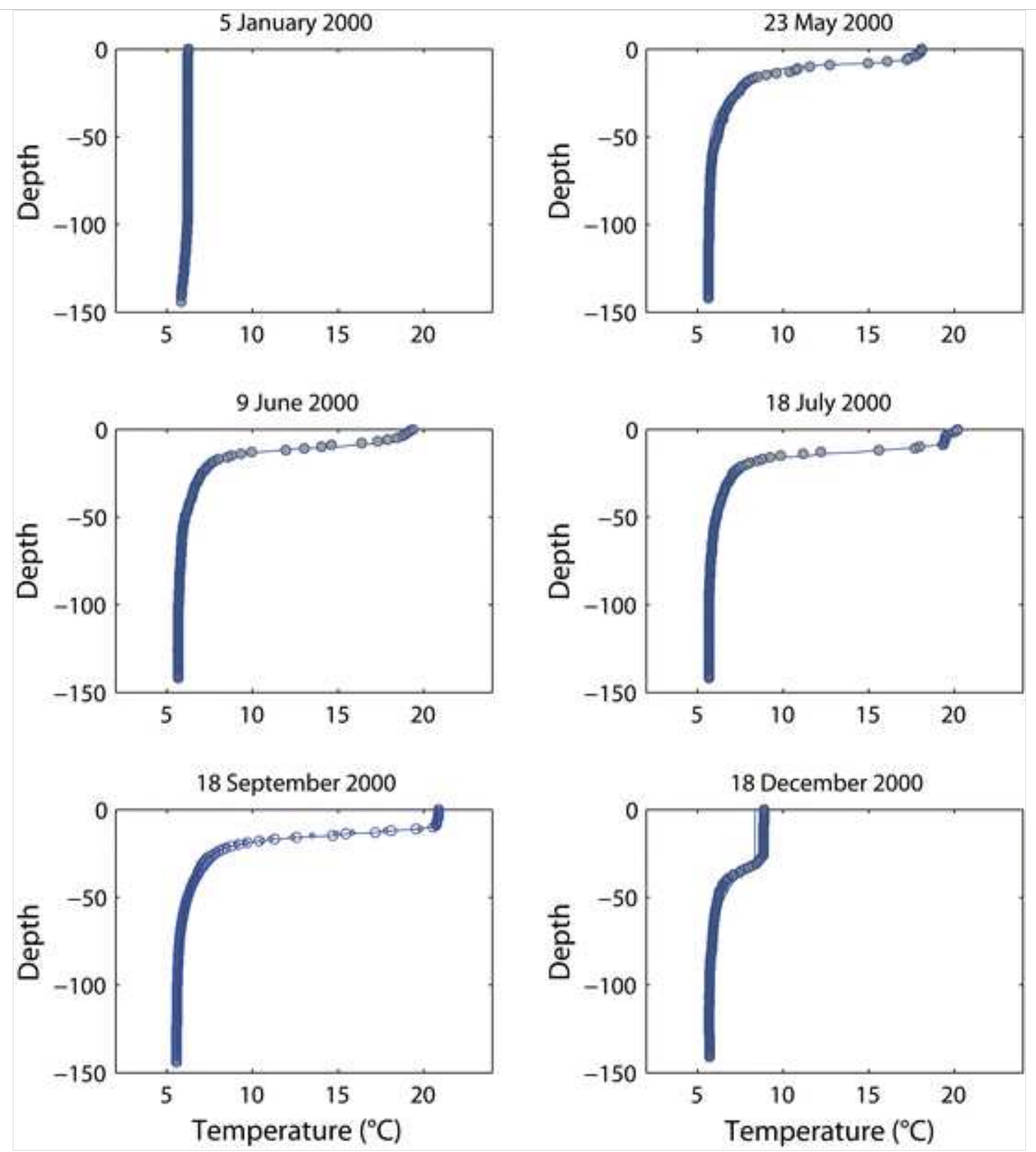

\section{Long-term continuous simulation}

A continuous simulation was performed for a 33-year period, from January 1976 to December 2008. The values of the model parameters were those obtained during the calibration process. Again, the daily extinction coefficient was estimated from the Secchi depth, linearly interpolated between the dates of the measurements. The results are presented in Fig. 3 .

\section{Fig. 3}

Results of the long-term simulation (1976-2008) at 2-m depth (below the surface), 12-m depth (around the thermocline depth) and 120-m depth (close to the bottom) 

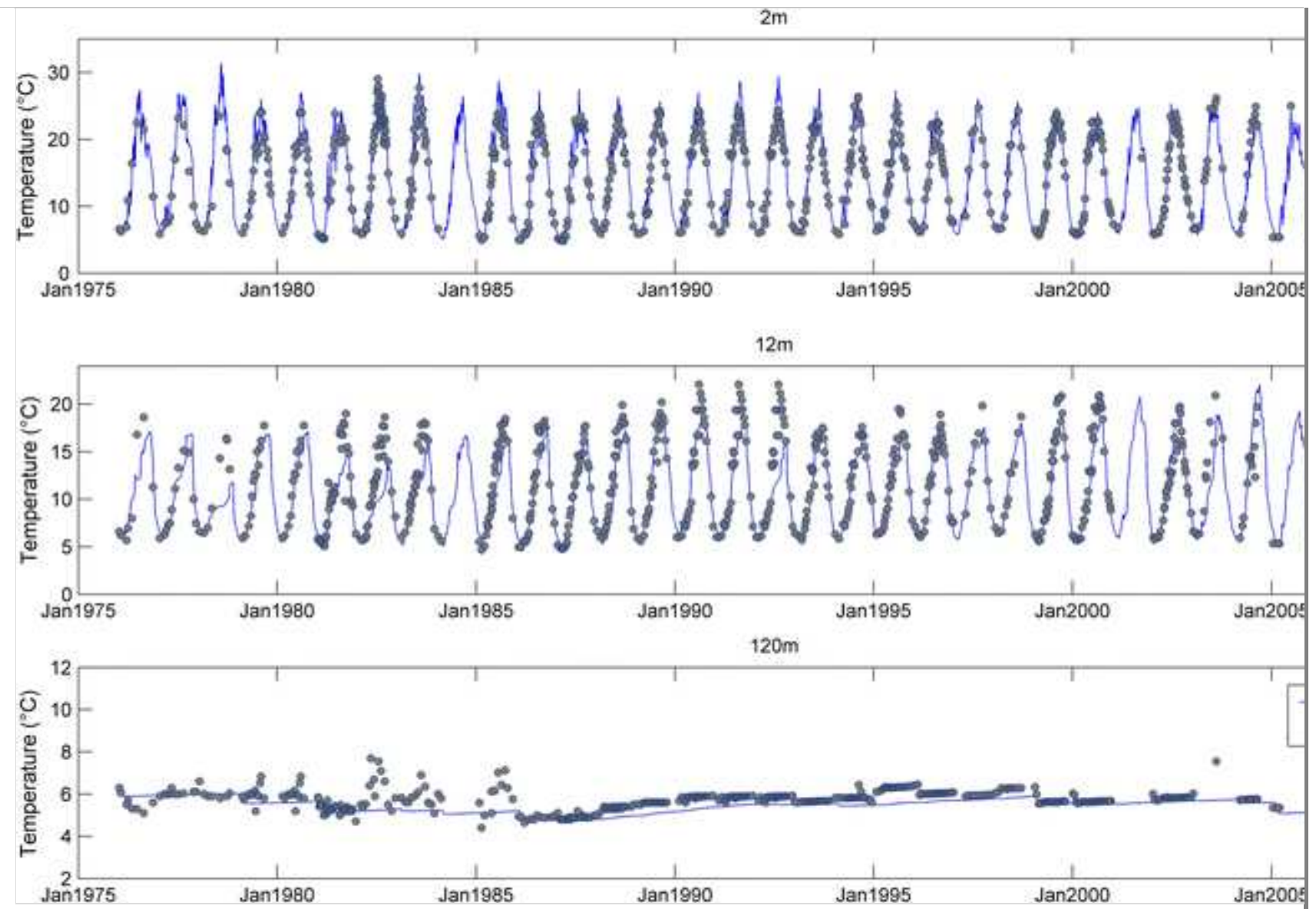

A global assessment of the long-term model performance is provided by the mean values of the three indicators ( $T_{\mathrm{me}}, T_{\text {sde }}$ and $T_{\text {rmse }}$ ), computed for the period 1976-2008 (Fig. 4). For calculating these indicators, three layers are defined: 0-5, 5-25 and $25 \mathrm{~m}$ bottoms. During most of the stratification period, the 0-5 m layer corresponds to the epilimnion, the 5-25 m layer contains the thermocline, and the 25 m-bottom layer corresponds to the hypolimnion.

\section{Fig. 4}

Indicators: $T_{\text {me }}$ (left), $T_{\text {sde }}$ (middle) and $T_{\text {rmse }}$ (right) of the model performance in the $0-5,5-25$ and $25 \mathrm{~m}$ bottom layers: mean values during the period 1976-2008 


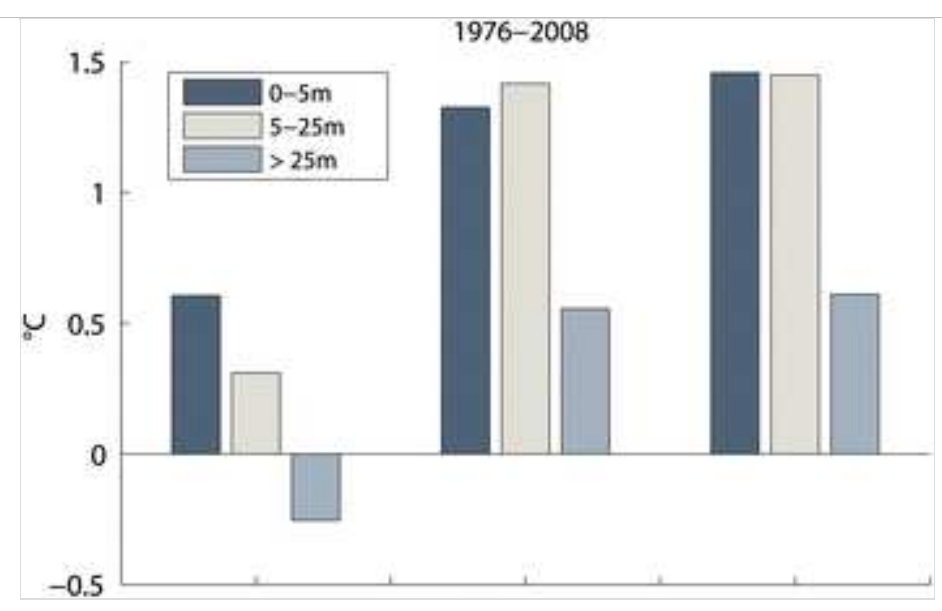

In the $0-5 \mathrm{~m}$ and the 5-25 $\mathrm{m}$ layers, the model slightly overestimates the mean water temperature $\left(T_{\text {me }}\right)$ by 0.6 and $0.3{ }^{\circ} \mathrm{C}$, respectively. In the bottom layer, the water temperatures are slightly underestimated $\left(-0.2{ }^{\circ} \mathrm{C}\right)$ by the model. In the $0-5 \mathrm{~m}$ and the 5-25 $\mathrm{m}$ layers, the standard deviation of the errors $\left(T_{\mathrm{sde}}\right)$ and the root mean square of the errors $\left(T_{\text {rmse }}\right)$ have similar values, around $1.5^{\circ} \mathrm{C}$. In the bottom layer they are lower, around $0.5^{\circ} \mathrm{C}$.

In order to check whether the model performance varies with the seasons, the monthly mean errors and monthly means of the root mean square errors were computed (Fig. 5). There is no seasonal pattern in the mean errors. In the 0-5 $\mathrm{m}$ and the 5-25 m layers, the monthly means of the root mean square of the errors $T_{\text {rmse }}$ are small, lower than $1.5{ }^{\circ} \mathrm{C}$ whatever the month, but stronger in spring and summer.

\section{Fig. 5}

Monthly mean errors $T_{\text {me }}$ (left) and monthly means of the root mean square errors $T_{\text {rmse }}(r i g h t)$ in the $0-5,5-25$ and $25 \mathrm{~m}$ bottom layers during the 1976-2008 simulation. The error bars refer to the standard deviation of the yearly values for the simulation period 

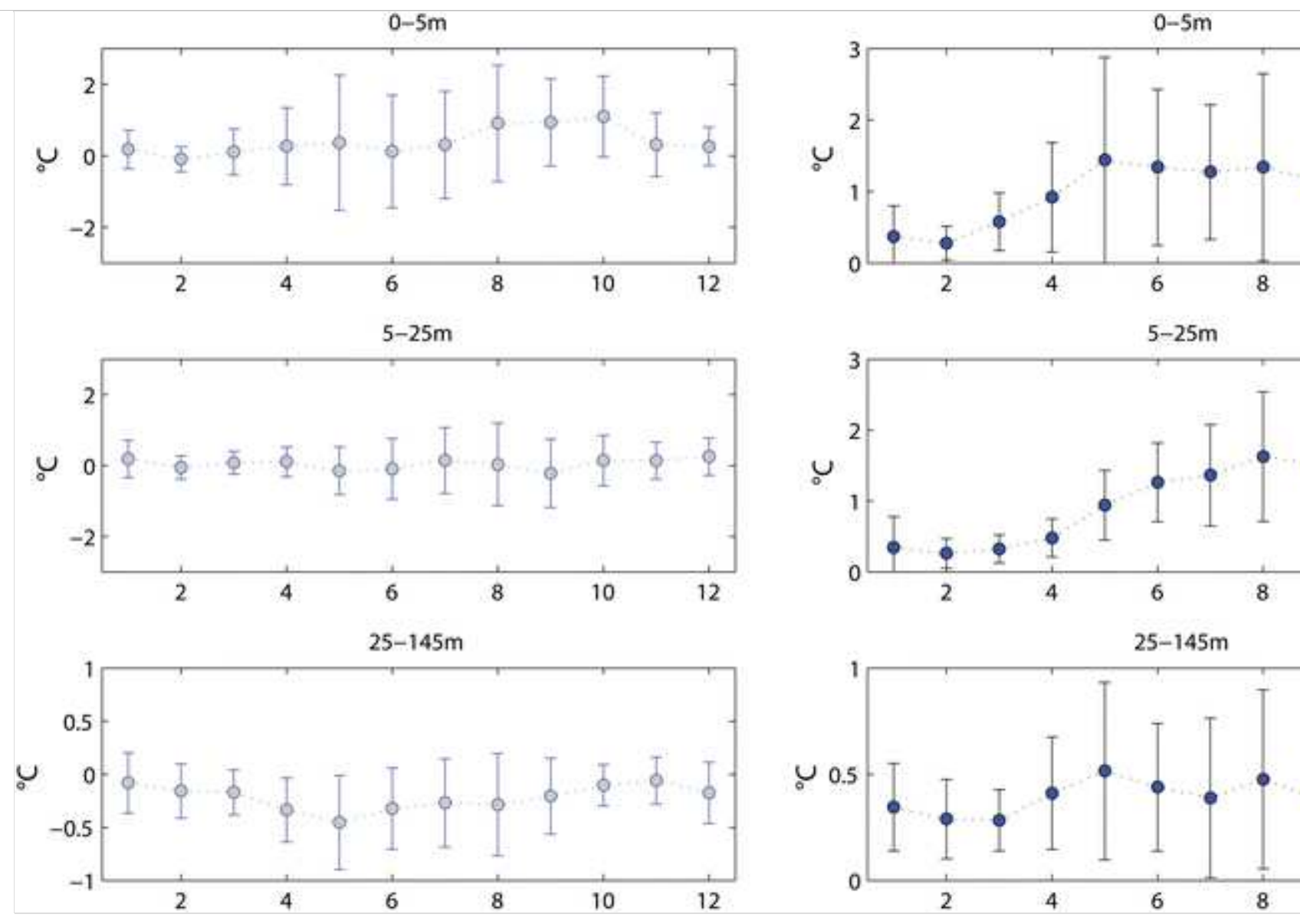

In the bottom layer, $T_{\text {rmse }}$ values are very small, lower than $0.5^{\circ} \mathrm{C}$. The evolution of the model performance was assessed during the whole simulation period by computing for each year the root mean square error averaged over the whole lake water column and the year (Fig. 6). No amplification of the errors occurred in the long-term simulation.

Fig. 6

Annual mean of the root mean square errors $T_{\text {rmse }}$ of the lake water temperature (1976-2008 simulation)

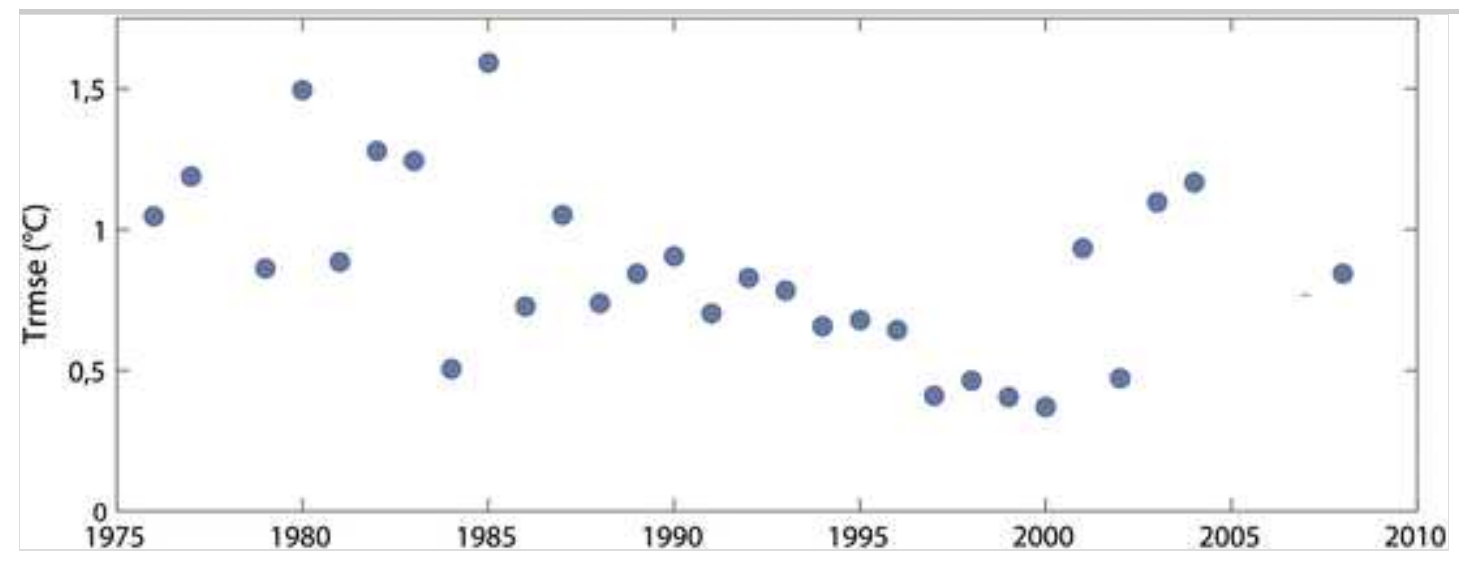

The long-term trend 
Mean annual air temperature increased strongly and significantly over the period 1976-2008, with a mean rate of increase of around $0.56{ }^{\circ} \mathrm{C} /$ decade ( $r=0.89, P<0.00001, n=33$ ), but with strong fluctuations (Fig. 7 a).

\section{Fig. 7}

a Annual mean of air temperature (Météo-France station of Voglans), b annual mean of lake temperature and $\mathbf{c}$ annual mean of the Schmidt stability
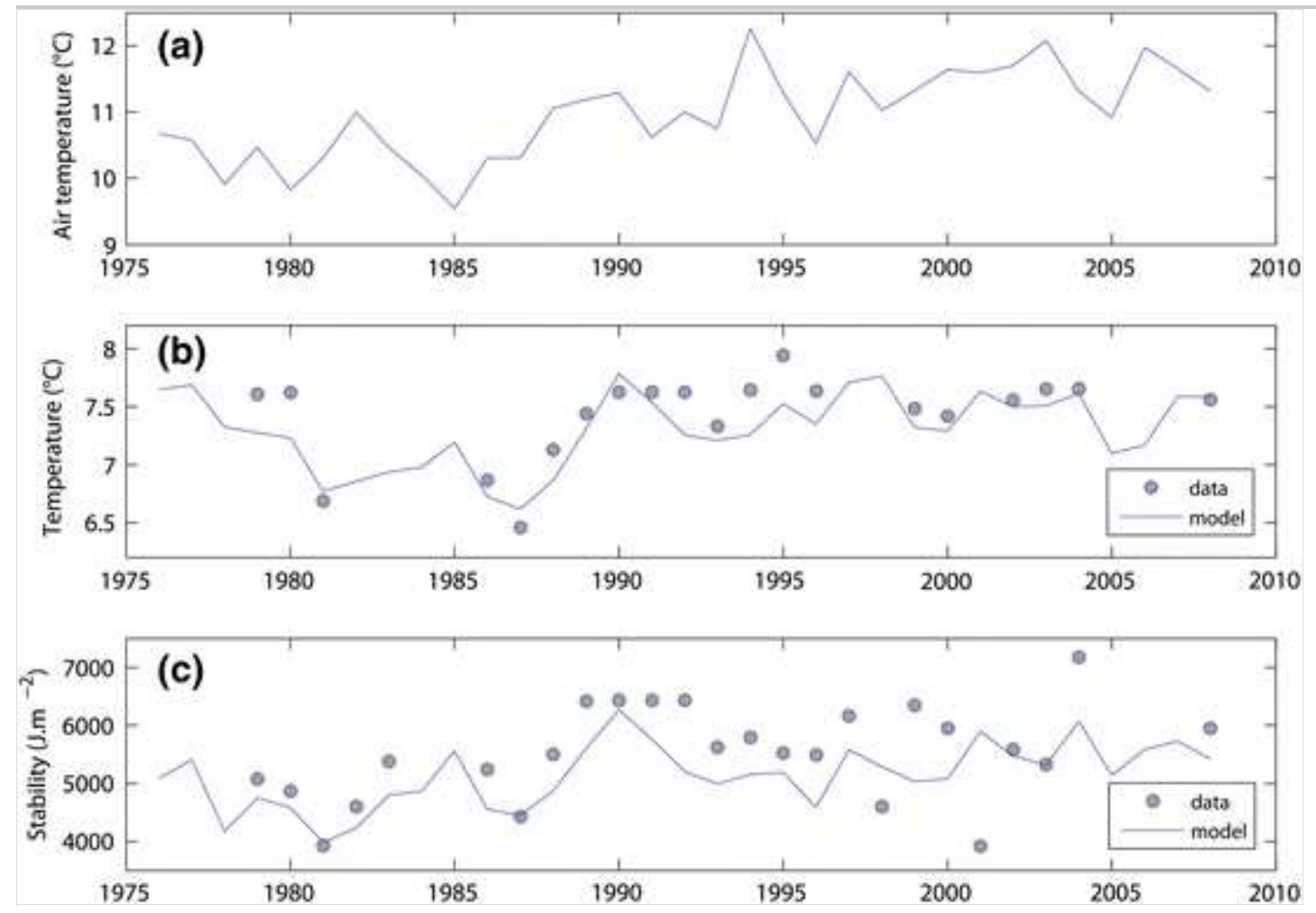

To analyse long-term trends in the thermal regime of Lake Bourget, five indicators were used: the mean annual water temperature, the mean annual Schmidt stability, the starting and ending days of stratification and the duration of the seasonal stratification.

We first assessed the trend using the measured water profiles. Among the 33 years of the study period, we discarded 13 years because the measurement accuracy was insufficient or because the sampling frequency was too low. We retained a subset of 20 years with reliable data. Morever, the model was used to check whether it can improve the statistical significance of the trend, first on the 20-year subset and then on the whole study period.

Trend assessment based on the measurements

The mean annual water temperatures computed from the subset of field 
measurements from the period 1976-2008 are plotted in Fig. 7b. The field data show an increasing trend of $0.19{ }^{\circ} \mathrm{C} /$ decade, which is, however, not statistically significant $(n=20, P>0.05)$.

The yearly mean stability index was computed according to Eq. 8 for the 20-year subset and is plotted in Fig. 7c. It significantly increased by $51 \mathrm{~J} \mathrm{~m}^{-2} \mathrm{y}^{-1}(n=20, r=0.55, P<0.05)$. The Schmidt stability computed at the seasonal scale does not show any statistically significant trend whatever be the season.

Trend assessment based on the model results

The mean lake temperature (Fig. 7b) computed from the model results for the 20-year subset, significantly increases by $0.22{ }^{\circ} \mathrm{C} /$ decade

( $n=20, r=0.57, P<0.01)$. For the whole data set, the increase rate is smaller, $0.12{ }^{\circ} \mathrm{C} /$ decade $(n=33, r=0.35, P<0.05)$.

The Schmidt stability computed with the Model results for the 20-year subset increased by $36 \mathrm{~J} \mathrm{~m}^{-2} \mathrm{y}^{-1}(n=20, r=0.53, P<0.05)$. For the whole data set, the increase rate is comparable, $31 \mathrm{~J} \mathrm{~m}^{-2} \mathrm{y}^{-1}(n=33, r=0.55, P<0.001)$. The seasonal Schmidt stability showed an increasing trend whatever be the season, but significant only for spring $(n=33, r=0.46, P<0.01)$ and summer $(n=33, r=0.47, P<0.01)$.

The root mean square error of the Schmidt stability computed with the 20-year subset of model results and measurements is $556 \mathrm{~J} \mathrm{~m}^{-2} \mathrm{y}^{-1}$, corresponding to $10 \%$ of the mean Schmidt stability value during this period. This value indicates a good agreement between the stability computed with the measurements and with the model results.

We also looked at the evolution of the duration of thermal stratification, using a criterion based on the stability index. The onset of stratification occurred significantly earlier by 3.0 days/decade $(n=33, r=-0.42, P<0.01)$, whereas the end of stratification did not show any significant trend. However, the stratification duration showed a significant increase of around 5.9 days/decade $(r=0.53, P<0.001)$.

The statistically significant changes in the mean annual values of the lake temperature, water column stability and stratification duration computed according to the data and the model results are summarised in Table 6. 


\section{Discussion}

\section{Model performance}

The discrepancy between the model results and the measured values is greatest during the first 12 years (1976-1987) of the simulation period (Fig. 6). This is mainly due to the poorer quality of many measurements, which caused a large dispersion of the measured water temperature. Looking at the variations of the hypolimnion temperature, which is not expected to vary by more than $0.5^{\circ} \mathrm{C}$ during the stratification period, we estimated the data uncertainty as $1.5^{\circ} \mathrm{C}$. The inaccuracy of some measurements is not due to low thermometer accuracy $\left(0.1^{\circ} \mathrm{C}\right)$ but rather to an excessive lag time between the water sampling and the measurement on the boat. Moreover, as Lake Bourget is very deep, the uncertainty in the depth was high for the sampling in the hypolimnion.

Since 1988, the measurements were performed with underwater temperature and depth sensors, and therefore the reliability of the data greatly improved. But, until 1995, the sensor response time remained high. In the same way as explained previously, we estimated the uncertainty as about $1{ }^{\circ} \mathrm{C}$. Since 1996 , the quality of the data is adequate, but for a few years, the number of available temperature profiles is not sufficient for computing reliable annual means.

The simulated temperatures are slightly lower than the measured ones: first because the field surveys always occurred around mid-day and in good weather, and second because the results of the model are 24-h averages.

We have compared values of the performance indicators of the present simulations with the values of several modelling studies on similar sub-alpine lakes: Lake Zürich with SIMSTRAT (Peeters et al., 2002), Lake Ammer with DYRESM (Weinberger \& Vetter, 2012) and Lake Geneva with four different models (Perroud et al., 2009).

Peeters et al. (2002) performed with SIMSTRAT a 50-year long continuous simulation (1958-1997) of Lake Zürich (136 m deep). They obtained a difference of $0.18 \pm 0.37{ }^{\circ} \mathrm{C}\left(T_{\text {me }} \pm T_{\text {sde }}\right)$ between the measured and simulated mean lake temperature and a root mean square error $T_{\text {rmse }}$ of $0.23{ }^{\circ} \mathrm{C}$. With the Lake Bourget 33-year simulation, we obtained similar values: a mean error of $0.15 \pm 0.18^{\circ} \mathrm{C}$ for the mean lake temperature and a root mean square error of $0.73{ }^{\circ} \mathrm{C}$. Peeters et al. (2002) also computed $T_{\text {rmse }}$ in the epi- and metalimnion considered together and in the hypolimnion, 0.77 and $0.34{ }^{\circ} \mathrm{C}$, 
respectively. In Lake Bourget, we computed separately $T_{\text {rmse }}$ for the 0-5, 5-25 and $25-\mathrm{m}$ bottom layers. The values are $1.5^{\circ} \mathrm{C}$ for the $0-5$ and $5-25 \mathrm{~m}$ layers and $0.5{ }^{\circ} \mathrm{C}$ for the bottom layer. These are of the same magnitude as in Lake Zürich but approximately $50 \%$ higher.

In Lake Ammer (83 m deep), Weinberger \& Vetter (2012) computed $T_{\text {rmse }}$ for the 4-year calibration period 2004-2007 and the 7-year validation period 1993-1997. In the epilimnion, the values for the validation and calibration periods were around 1.6 and $2{ }^{\circ} \mathrm{C}$, respectively. In the metalimnion, the values from both the calibration and validation periods were around $1.5^{\circ} \mathrm{C}$. No values were mentioned for the hypolimnion. The Lake Ammer values are in the same range as the value of $1.5{ }^{\circ} \mathrm{C}$ found for Lake Bourget $0-5$ and $5-25 \mathrm{~m}$ layers during the 33 -year simulation period.

The four models applied to Lake Geneva are an eddy-diffusive model, HLM (Hostetler \& Small, 1999); a variable-depth-layer model, DYRESM (Imberger $\&$ Patterson, 1981); a $k-\varepsilon$ turbulence model, SimStrat (Goudsmit et al., 2002 ); and a model based on the concept of self-similarity of the temperature-depth curve, the FLAKE model (Mironov, 2008). In that study, the authors ran the four models over a 10-year period, from 1996 to 2005, using hourly values of meteorological forcing variables. The simulations were performed in a discontinuous mode, i.e. each yearly simulation was initialized with the last measured profile of the previous year. The authors defined three disjointed layers: $0-10 \mathrm{~m}$ for the epilimnion, $15-35 \mathrm{~m}$ for the metalimnion and 50-300 $\mathrm{m}$ for the hypolimnion.

The $T_{\text {rmse }}$ values obtained for the $0-5 \mathrm{~m}$ layer in Lake Bourget $\left(1.5^{\circ} \mathrm{C}\right)$ are comparable to those obtained for Lake Geneva 0-10 m layer with the models HLM, SIMSTRAT and DYRESM, and better than those obtained with the FLAKE model (around $3{ }^{\circ} \mathrm{C}$ ). Regardless of the model employed, the $T_{\text {rmse }}$ values obtained for the 5-25 $\mathrm{m}$ layer in Lake Bourget $\left(1.5^{\circ} \mathrm{C}\right)$ are better than those obtained in the corresponding layer in Lake Geneva (15-35 m), which were around $6.5{ }^{\circ} \mathrm{C}$ for HLM, around $3{ }^{\circ} \mathrm{C}$ for DyRESM, around $2.5{ }^{\circ} \mathrm{C}$ for SiMSTRAT and around $4{ }^{\circ} \mathrm{C}$ for FlAKE. For the bottom layer, the values are comparable $\left(0.5^{\circ} \mathrm{C}\right)$.

Based on the comparison with these results summarised in Table 7, particularly with those obtained with four well-recognized models run in a more favourable configuration (10-year discontinuous simulation) on Lake Geneva, we can conclude that the achievement of the Lake Bourget model, 
continuously run on a 33-year period, is quite satisfactory.

Table 6

Trend assessment of the thermal regime of Lake Bourget

\begin{tabular}{|c|c|c|c|c|c|c|}
\hline & \multicolumn{3}{|l|}{ Data } & \multicolumn{3}{|l|}{ Model } \\
\hline & Temperature & $\begin{array}{l}\text { Stability } \\
\left(\mathrm{J} \mathrm{m}_{-2} \mathrm{y}^{-1}\right)\end{array}$ & Duration & $\begin{array}{l}\text { Temperature } \\
\left.\text { ( }{ }^{\circ} \mathrm{C} / \text { decade }\right)\end{array}$ & $\begin{array}{l}\text { Stability } \\
\left(\mathrm{J} \mathrm{m}^{-2} \mathrm{y}^{-1}\right)\end{array}$ & Dur: \\
\hline$n=20$ & - & 51 & - & 0.22 & 36 & - \\
\hline$n=33$ & - & - & - & 0.12 & 31 & $\begin{array}{l}5.9 \\
\text { Days }\end{array}$ \\
\hline
\end{tabular}

Using a $5 \%$ significance level, the statistically significant changes in the mean annual of lake temperature, water column stability and stratification duration were computed the measurements and from the model results, for the whole study period $(n=33)$ anc 20 -year subset of reliable data $(n=20)$

\section{Table 7}

Performance indicator values $\left(T_{\text {rmse }}\right)$ of sub-alpine lake models

\begin{tabular}{|c|c|c|c|c|c|c|}
\hline \multirow[b]{2}{*}{ Lake } & \multirow[b]{2}{*}{ Period } & \multirow[b]{2}{*}{ Model } & \multicolumn{4}{|l|}{ RMSE } \\
\hline & & & $\begin{array}{l}\text { Whole } \\
\text { lake } \\
\left({ }^{\circ} \mathrm{C}\right)\end{array}$ & $\begin{array}{l}\text { Epilimnion } \\
\left({ }^{\circ} \mathrm{C}\right)\end{array}$ & $\begin{array}{l}\text { Metalimnion } \\
\left({ }^{\circ} \mathrm{C}\right)\end{array}$ & $\begin{array}{l}\text { Hypolim n } \\
\left({ }^{\circ} \mathrm{C}\right)\end{array}$ \\
\hline Zürich & $1958-1997$ & SIMSTRAT & 0.23 & 0.77 & & 0.34 \\
\hline \multirow{4}{*}{ Geneva } & \multirow{4}{*}{ 1996-2005 } & DYRESM & - & 1.5 & 3 & 0.5 \\
\hline & & SIMSTRAT & - & 1.5 & 2.5 & 0.5 \\
\hline & & HLM & - & 1.5 & 6.5 & 0.5 \\
\hline & & FLAKE & - & 3 & 4 & 0.5 \\
\hline \multirow{2}{*}{ Ammer } & 2004-2007 & \multirow{2}{*}{ DYRESM } & - & 1.6 & 1.5 & - \\
\hline & 1993-1997 & & - & 2 & 1.5 & - \\
\hline Bourget & $1976-2008$ & $\begin{array}{l}\text { this } \\
\text { model }\end{array}$ & 0.23 & 1.5 & 1.5 & 0.5 \\
\hline
\end{tabular}




\section{Evolution of the air temperature}

At the global scale, between 1906 and 2005, air temperature increased by

$0.74{ }^{\circ} \mathrm{C}$ over the whole century, and by $0.1{ }^{\circ} \mathrm{C} /$ decade between 1987 and 2006 (IPCC, 2007). In the European Alps, the rate of increase was higher:

depending on location, the air temperature increased by $1-1.4^{\circ} \mathrm{C}$ during last century and by around $0.5^{\circ} \mathrm{C} /$ decade between 1982 and 2006 (Auer et al., 2007).

The most intense warming, registered in the 1990s, is linked to high values of the North Atlantic Oscillation (NAO) index (Beniston, 2006). For the lakes located in the southern Alps, according to Salmaso (2012), the winter lake temperature and, therefore, the duration of lake winter overturn are strongly linked to two other large-scale climatic indices, the East Atlantic (EA) pattern and the Eastern Mediterranean Pattern (EMP).

Lake Bourget is the southernmost and westernmost of the European sub-alpine lakes. In its vicinity, from 1976 to 2008, the mean rate of increase of the air temperature was $0.56^{\circ} \mathrm{C} /$ decade, which is of the same magnitude as for the whole European Alps region, but with strong fluctuations (Fig. $7 \mathrm{a}$ ). Looking in more detail, there was a step-wise evolution with a strong shift in the air temperature at the end of 1980s, dividing the 1976-1987 and 1988-2008 periods. The same shift was observed in the whole Alps region in 1987-1988. It was associated with a shift in the Artic oscillation (North et al., 2013 ).

\section{Water temperature trend}

During the first 10 years of the study period, the accuracy of the measurements was low, and a small number of profiles were measured in some years. The values in the years with too few measurements (fewer than 2 profiles per season) had to be discarded (e.g. 2005-2007). In a few years, e.g. 1986 and 1995, the uneven distribution of the measured profiles during the year impairs the accuracy of the annual mean temperature.

Due to the heterogeneity of the time series over the whole period, no statistically significant overall trend can be detected $(P>0.05)$. However, application of the model does reveal a trend in the water temperature (Fig. 7b). Comparing the rate of increase in the simulated temperature for the 20-year subset $\left(0.22^{\circ} \mathrm{C} /\right.$ decade $)$ and for the whole study period $\left(0.12{ }^{\circ} \mathrm{C} /\right.$ decade) shows the importance of filling the gaps of the measured 
time series using the model.

In the same period, the air temperature increased by around $0.56{ }^{\circ} \mathrm{C} / \mathrm{decade}$. Therefore, the mean increase in the lake water temperature represents about $20 \%$ of the increase in air temperature. This rate of increase is lower than that observed in Lake Constance from 1962 to 1998 by Straile et al. (2003): the mean water temperature there increased by $0.17^{\circ} \mathrm{C} /$ decade, which represents approximately one-third of the increase in air temperatures. In Lake Zürich, between 1947 and 1998, the rate of increase in the mean lake temperature, based on the decadal running means, was $0.16{ }^{\circ} \mathrm{C} /$ decade (Livingstone, 2003), which is also higher than in Lake Bourget. However, the water temperature increase in Lake Bourget is not strictly comparable to these two other lakes because the study periods are different. Our study period started 20 years later than on Lake Zürich and 14 years later than on Lake Constance and it ended 10 years later than on both Lake Zürich and Constance.

In Lake Bourget, the mean lake water temperature is more significantly correlated with the winter air temperature $(n=33, r=0.61, P=0.0002)$ than with the annual mean air temperature. A similar result ( $n=37, r=0.88, P<0.0001$ ) was obtained for Lake Constance from 1962 to 1998 by Straile et al. (2003).

Looking in more detail, it appears that the simulated water temperature decreased significantly $(r=0.84, P<0.001)$ during the first 12 years (1976-1988). However, there was no significant trend during the following 21 years (1989-2008). These features partly differ from those observed in Lake Zürich (Livingstone, 2003 ), where a strong decrease occurred from 1978 to 1982 , similar to the one observed in Lake Bourget, but the increasing trend resumed during the following years. Moreover, recent works on Lake Constance (Jochimsen et al., 2013) and on Swiss lakes (Lake of Walenstadt, Lake Greifen and Lake Zürich) (North et al., 2013) show that the thermal regime in those lakes was affected by the abrupt climate shift which occurred in the late 1980s throughout the Northern Hemisphere. The long-term temperature trends in Lake Constance (1965-2007), in Lake Zürich and Lake Greifen (1972-2005) and in Lake of Walenstadt (1972-2000) are best described by a step-wise function rather than by a linear trend.

\section{Schmidt stability and duration of the stratification}

Like the mean lake temperature, the stability computed from the simulated 
temperatures allows us to infer the existence of a significant trend ( $n=33, r=0.55, P<0.0001$ ) during the study period. According to the model, the stability of the water column in Lake Bourget increased by about $20 \%$ from 1976 to 2008. This increase is faster than in Lake Zürich, where the same $20 \%$ increase in thermal stability occurred during a longer period, from the 1950s to the 1990s (Livingstone, 2003).

Regarding the duration of the stratification period, we considered that the interval between monitoring dates of around one month was too long to allow us to seek a significant trend in the field data. Using the model results, a significant increase of 5.9 days/decade $(n=33, r=0.53, P<0.001)$ was evidenced. This value can be compared to the increase of the stratification duration estimated by 2-3 weeks between the 1950s and the 1990s in Lake Zürich (Livingstone, 2003 ).

\section{Conclusions and perspectives}

We have shown that the one-dimensional thermal model which we applied to Lake Bourget is well adapted for simulating the long-term evolution of the temperature of this deep, sub-alpine lake. The performance of this model, based on the horizontally averaged diffusion equation for temperature and on a simple parameterization of the eddy diffusivity, was assessed through usual indicators. The quality of the results is comparable to the best existing one-dimensional models.

We also showed that this model can provide surrogates for missing measurements and reconstitute long-term time series of lake water temperature. The results of a 33-year simulation using this model allowed us to infer the existence of a long-term increase in water temperature in Lake Bourget. The rate of increase is lower than in Lake Constance and Lake Zürich. However, the annual mean stability increased more rapidly in Lake Bourget than in Lake Zürich. When long meteorological time series are available, hindcast simulations could help to reconstitute the long-term trend in the water temperature of other sub-alpine lakes.

\section{Acknowledgements}

We thank Cisalb and especially Gérard Paolini for providing us with temperature data and Secchi depths of many years of the study period. We express our gratitude to Naiara Belucci and Victor Penot, interns at Leesu-Ecole des Ponts ParisTech for their valuable help in the model 
simulations and to John Gedge for the revision of the English text. The last step of this research was supported by the French observatory of sub-alpine lakes, SOERE-GLACPE (Systèmes d'Observation et d'Expérimentation au long terme pour la Recherche en Environnement-Grands LACs PEri-alpins). We thank Orlane Anneville (INRA Thonon-les-Bains) for fruitful discussions.

\section{References}

Adrian, R., C. M. O’Reilly, H. Zagarese, S. B. Baines, D. O. Hessen, W. Keller, D. M. Livingstone, R. Sommaruga, D. Straile, E. Van Donk, G. A. Weyhenmeyer \& M. Winder, 2009. Lakes as sentinels of climate change. Limnology and Oceanography 546: 2283-2297.

Anneville, O., \& J. P. Pelletier, 2000. Recovery of Lake Geneva from eutrophication: quantitative response of phytoplankton. Archiv Fur Hydrobiologie 148(4): 607-624.

Anneville O, V. Ginot, J. C. Druart \& N. Angeli, 2002. Long-term study (1974-1998) of seasonal changes in the phytoplankton in lake geneva: a multi-table approach. Journal of Plankton Research 24(10): 993-1008.

Auer, I., R. Bohm, A. Jurkovic, W. Lipa, A. Orlik, R. Potzmann, W. Schoner, M. Ungersbock, C. Matulla, K. Briffa, P. Jones, D. Efthymiadis, M. Brunetti, T. Nanni, M. Maugeri, L. Mercalli, O. Mestre, J. M. Moisselin, M. Begert M, G. Muller-Westermeier, V. Kveton, O. Bochnicek, P. Stastny, M. Lapin, S. Szalai, T. Szentimrey, T. Cegnar, M. Dolinar, M. Gajic-Capka, K. Zaninovic, Z. Majstorovic \& E. Nieplova, 2007. Histalp -historical instrumental climatological surface time series of the greater alpine region. International Journal of Climatology 27(1): 17-46.

Beniston, M., 2006. Mountain weather and climate: a general overview and a focus on climatic change in the Alps. Hydrobiologia 562: 3-16.

Brunetti, M., G. Lentini, M. Maugeri, T. Nanni, I. Auer, R. Böhm \& W. Schöner, 2009. Climate variability and change in the Greater Alpine Region over the last two centuries based on multi-variable analysis. International Journal of Climatology 29(15): 2197-2225.

Bueche, T. \& M. Vetter, 2013. Simulating water temperatures and stratification of a pre-alpine lake with a hydrodynamic model: calibration 
and sensitivity analysis of climatic input parameters. Hydrological Processes.

Chahuneau, F., 1984. Modélisation saisonnière du lac de Nantua. Verh Internat Limnol 22: 125-131.

Chahuneau, F., S. Des Clers \& J. Meyer, 1983. Analysis of prediction uncertainty: Monte Carlo simulation and non-linear least-squares estimation of a vertical transport submodel for Lake Nantua. In Beck, M. \& G. van Straten (eds), Uncertainty and Forecasting of Water Quality. Springer, New York.

Cuypers, Y., B. Vinçon-Leite, A. Groleau, B. Tassin \& J. F. Humbert, 2011. Impact of internal waves on the spatial distribution of Planktothrix rubescens (cyanobacteria) in an alpine lake. ISME Journal 5: 580-589.

Dokulil, M. T. \& K. Teubner, 2005. Do phytoplankton communities correctly track trophic changes? An assessment using directly measured and palaeolimnological data. Freshwater Biology 50(10): 1594-1604.

Dokulil, M. T., A. Jagsch, G. D. George, O. Anneville, T. Jankowski, B. Wahl, B. Lenhart, T. Blenckner \& K. Teubner, 2006. Twenty years of spatially coherent deepwater warming in lakes across Europe related to the North Atlantic Oscillation. Limnology and Oceanography 51(6): 2787-2793.

Dokulil, M. T., K. Teubner, A. Jagsch, U. Nickus, R. Adrian, D. Straile, T. Jankowski, A. Herzig \& J. Padisak, 2010. The impact of climate change on lakes in Central Europe. In George, G. (eds), The Impact of Climate Change on European Lakes, Aquatic Ecology Series, vol 4. Springer, Dordrecht: 387-409.

Fang, X., \& H. G. Stefan, 1999. Projections of climate change effects on water temperature characteristics of small lakes in the contiguous U.S. Climatic Change 42(2): 377-412.

Gallina, N., N. Salmaso, G. Morabito \& M. Beniston, 2013. Phytoplankton configuration in six deep lakes in the peri-alpine region: are the key drivers related to eutrophication and climate? Aquatic Ecology 47(2): 177-193. 
Goudsmit, G. H., H. Burchard, F. Peeters \& A. Wuest, 2002. Application of $k-\varepsilon$; turbulence models to enclosed basins: the role of internal seiches. Journal of Geophysical Research 107(C12): 3230-3243.

Henderson-Sellers, B, 1984. Engineering Limnology. Pitman Advanced Publishing Program, London.

Hondzo, M., \& H. G. Stefan, 1993. Lake water temperature simulation model. Journal of Hydraulic Engineering 119: 1251-1273.

Hostetler, S. W., 2009. Use of models and observations to assess trends in the 1950-2005 water balance and climate of Upper Klamath Lake, Oregon. Water Resources Research 45(12).

AQ3

Hostetler, S. W., \& E. E. Small, 1999. Response of North American freshwater lakes to simulated future climates. Journal of the American Water Resources Association 35(6): 1625-1637.

Hutchinson, G. E, 1957. A Treatise on Limnology, vol I. Geography, Physics and Chemistry. Wiley, New York.

Imberger, J. \& J. C. Patterson, 1981. A dynamic reservoir simulation model: DYRESM. Academic Press, New York: 310-361.

Imberger, J. \& J. C. Patterson, 1990. Physical limnology. Advances in Applied Mechanics 27: 303-475.

IPCC, 2007. Climate Change 2007-Synthesis Report. Intergovernmental Panel on Climate Change.

Jacquet, S., J. F. Briand, C. Leboulanger, C. Avois-Jacquet, L. Oberhaus, B. Tassin, B. Vinçon-Leite, G. Paolini, J. C. Druart, O. Anneville \& J. F. Humbert, 2005. The proliferation of the toxic cyanobacterium Planktothrix rubescens following restoration of the largest natural French lake (Lac du Bourget). Harmful Algae 4(4): 651-672.

Jochimsen, M., R. Kümmerlin \& D. Straile, 2013. Compensatory dynamics and the stability of phytoplankton biomass during four decades of eutrophication and oligotrophication. Ecology Letters 16(1): 81-89. 
Le Vu, B., B. Vinçon-Leite, B. J. Lemaire, N. Bensoussan, M. Calzas, C. Drezen, J. F. Deroubaix, N. Escoffier, Y. Degres, C. Freissinet, A. Groleau, J. F. Humbert, G. Paolini, F. Prevot, C. Quiblier, E. Rioust \& B. Tassin, 2011. High-frequency monitoring of phytoplankton dynamics within the European water framework directive: application to metalimnetic cyanobacteria. Biogeochemistry 106(2): 229-242.

Livingstone, D., \& M. Dokulil, 2001. Eighty years of spatially coherent Austrian lake surface temperatures and their relationship to regional air temperature and the North Atlantic Oscillation. Limnology and Oceanography 46(5): 1220-1227.

Livingstone, D. M., 2003. Impact of secular climate change on the thermal structure of a large temperate central european lake. Climatic Change 57(1): 205-225.

Lorke, A., 2007. Boundary mixing in the thermocline of a large lake. Journal of Geophysical Research-Oceans 112(C9).

MacIntyre, S., K. M. Flynn, R. Jellison \& J. R. Romero, 1999. Boundary mixing and nutrient fluxes in Mono Lake, California. Limnology and Oceanography 44(3): 512-529.

Mellor, G., \& P. Durbin, 1975. The structure and dynamics of the ocean surface mixed layer. Journal of Physical Oceanography 5: 718-728.

Miquet, A., 1997. Regulation of the lac du Bourget (French Alps): environmental impact of new management rules. Revue de Géographie Alpine 85: 11-21.

Mironov, D. V., 2008. Parameterization of Lakes in Numerical Weather Prediction. Description of a Lake Model. COSMO Technical report 11, Deutscher Wetterdienst, Offenbach am Main.

North, R. P., D. M. Livingstone, R. E. Hari, O. Koester, P. Niederhauser \& R. Kipfer, 2013. The physical impact of the late 1980s climate regime shift on Swiss rivers and lakes. Inland Waters 3(3): 341-350.

Peeters, F., D. M. Livingstone, G. H. Goudsmit, R. Kipfer \& R. Forster, 2002. Modeling 50 years of historical temperature profiles in a large 
central european lake. Limnology and Oceanography 47(1): 186-197.

Perroud, M., S. Goyette, A. Martynov, M. Beniston, O. Anneville, 2009. Simulation of multiannual thermal profiles in deep Lake Geneva: a comparison of one-dimensional lake models. Limnology and Oceanography 54(5): 1574-1594.

Rempfer, J., D. M. Livingstone, C. Blodau, R. Forster, P. Niederhauser \& R. Kipfer, 2010. The effect of the exceptionally mild european winter of 2006-2007 on temperature and oxygen profiles in lakes in Switzerland: a foretaste of the future? Limnology and Oceanography 55(5): 2170-2180.

Reynolds, C. S., S. C. Maberly, J. E. Parker \& M. M. De Ville, 2012. Forty years of monitoring water quality in Grasmere (English Lake District): separating the effects of enrichment by treated sewage and hydraulic flushing on phytoplankton ecology. Freshwater Biology 57(2): 384-399.

Rosner, R., D. C. Muller-Navarra \& E. Zorita, 2012. Trend analysis of weekly temperatures and oxygen concentrations during summer stratification in Lake Plusssee: a long-term study. Limnology and Oceanography 57(5): 1479-1491.

Salmaso, N., 2012. Influence of atmospheric modes of variability on a deep lake south of the Alps. Climate Research 51(2): 125-133.

Salmaso, N. \& L. Cerasino, 2012. Long-term trends and fine year-to-year tuning of phytoplankton in large lakes are ruled by eutrophication and atmospheric modes of variability. Hydrobiologia 698(1): 17-28.

Salmaso, N., F. Decet \& R. Mosello, 1997. Chemical characteristics and trophic evolution of the deep subalpine Lake Garda (Northern Italy). Mem Ist ital Idrobiol 56: 51-76.

Schindler, D. W., 2009. Lakes as sentinels and integrators for the effects of climate change on watersheds, airsheds, and landscapes. Limnology and Oceanography 54(6, part 2): 2349-2358.

Schmidt, W., 1928. Uber Temperatur und Stabilitätsverhältnisse von Seen. Geografiska Annaler 10: 145-177. 
Simons, T., 1981. The Seasonal Climate of the Upper Ocean: Data Analysis and Model Development. Technical Report, National Water Research Institute, Burlington, ON.

Stefan, H., X. Fang \& M. Hondzo, 1998. Simulated climate change effects on year-round water temperatures in temperate zone lakes. Climatic Change 40(3-4): 547-576.

Straile, D., K. Johnk \& H. Rossknecht, 2003. Complex effects of winter warming on the physicochemical characteristics of a deep lake. Limnology and Oceanography 48(4): 1432-1438.

Straile, D., O. Kerimoglu, F. Peeters, M. C. Jochimsen, R. Kummerlin, K. Rinke \& K. O. Rothhaupt, 2010. Effects of a half a millennium winter on a deep lake-a shape of things to come? Global Change Biology 16(10): 2844-2856.

Tassin, B., 1986. Contribution à la modélisation écologique du lac Léman: Modèles physiques et biogéochimiques du lac. PhD thesis, Ecole Nationale des Ponts et Chaussées, Paris.

Thies, H., M. Tolotti, U. Nickus, A. Lami, S. Musazzi, P. Guilizzoni, N. L. Rose \& H. Yang, 2012. Interactions of temperature and nutrient changes: effects on phytoplankton in the Piburger See (Tyrol, Austria). Freshwater Biology 57(10): 2057-2075.

Vinçon-Leite, B., 1991. Contribution de la modélisation mathématique à l'étude de la qualité de l'eau dans les lacs sub-alpins: le lac du Bourget (Savoie). PhD thesis, Ecole Nationale des Ponts et Chaussées, Paris, 274 p.

Vinçon-Leite, B., J. M. Mouchel \& B. Tassin, 1989. Modélisation de l'évolution thermique saisonnière du lac du Bourget (Savoie, France). Revue des Sciences de 1'Eau 2: 483-510.

Weinberger, S. \& M. Vetter, 2012. Using the hydrodynamic model DYRESM based on results of a regional climate model to estimate water temperature changes at Lake Ammersee. Ecological Modelling 244(0): $38-48$. 
Williams, D., G. Drummond, D. Ford \& D. Robey, 1981. Determination of light extinction in lakes and reservoirs. In Stefan, H. (eds), Proceedings ASCE symposium on surface water impoundments, vol 2, Minneapolis, $\mathrm{MN}$. 